Geological and Marine Microbiology at the Florida State University

THE Florida State University, Department of Biological Sciences and Oceanographic Institute, is introducing a programme in geological and marine microbiology. The programme will be conducted by Carl H. Oppenheimer, formerly of the Marine Laboratory, University of Miami, and Prof. Wilhelm Schwartz, formerly head of the Institute of Microbiology, University of Greifswald. The programme will be closely affiliated with the Departments of Geology and Chemistry, thus providing a wide range of curricula needed for background in the many diversities in this science. The primary emphasis of the programme will be to train students in the laboratory and field. Field research will initially be confined, but not limited, to the many ecological parameters of the waters of the adjacent Gulf Coast. A limited number of assistantships are now available to qualified graduate students. Requirements include a basic scientific background in biology, chemistry, mathematics and, if possible, geology. Problems for research include marine microbiology, microbial ecology, pollution, sanitary aspects, diagenesis of organic matter and the origin of oil, geochemistry and microbial diagenesis of sediments, and economical aspects of microbial fouling, deterioration of plastics, corrosion, etc. Further information can be obtained from the Administrative Assistant, Florida State University, Tallahassee.

\section{Oliver Memorial Fund Award}

The Committee of the Oliver Memorial Fund for Blood Transfusion has announced its intention to make the seventeenth annual award of an inscribed plaque and a cash grant to any British subject, whose original work or service in the field of blood transfusion is considered by the adjudicators to be an outstanding contribution to the science, organization or donor aspect of this subject. The Committee will welcome communications directing their attention to suitable candidates and reserve the right to divide the award in the event of a tie. In accordance with the rules, the award will this year be restrictod to members of the medical profession. Further information can be obtained from Mrs. F. E. Bedborough, 27 Penarth Gardens, Thornlea Park, Littlehampton, Sussex. The closing date is May 30.

\section{University News}

Belfast

THE following lecturers have been appointed: Dr. B. J. S. Barnard and Mr. A. Jennings (civil engineering); Dr. P. F. Binnion (physiology); Mr. D. T. Bickley and Dr. J. Dunwoody (engineering mathematics).

\section{London}

Mr. P. H. HIRst has been appointed to the chair of education tenable at King's College. Dr. J. H. E. Jeffes, lecturer at the Imperial College of Science and Technology, has been appointed to the readership in extraction metallurgy tenable at that College. The following titles have been conferred: Professor, Dr. F. H. Ludlam (meteorology, at the Imperial College of Science and Technology); Dr. W. H. McMenemey (pathology, at the Institute of Neurology); Dr. A. G. E. Pearse (histochemistry, at the Postgraduate Medical School of London); Reader, Dr. D. K. Butt (physics, at Birkbeck College); Dr. A. Elliott (biophysics, at King's College); Dr. K. S. Kirby (chemistry, at the Institute of Cancer Research, Royal Cancer Hospital).

Sheffield

DR. J. R. QUAYLE, senior lecturer in biochemistry, has been appointed to the West Riding chair of microbiology from July 1. Dr. J. P. C. Roach, Fellow of Corpus Christi College and university lecturer in education in the University of Cambridge, has been appointed director of the Institute of Education and professor of education in the Institute. The following lecturers have also been appointed: Mr. W. R. A. Ellis (geography and education, tenable at the Institute of Education); Mr. R. L. Wright (geography).

\section{Announcements}

Dr. George Gaylord Simpson, of the Museum of Comparative Zoology in Harvard University, has been awarded for the second time the Daniel Giraud Elliot Medal of the U.S. National Academy of Sciences-the first instance in the 48-year history of the award that the same person has twice been named recipient. The Elliot Medal is given for the most meritorious published work in zoology or palaeontology during a previous year, and is presented to Dr. Simpson in recognition of his book, Principles of Animal Taxonomy, published in 1961 by the Columbia University Press.

Mr. G. C. EDDIE, who was seconded for three years to the White Fish Authority by the Department of Scientific and Industrial Research in April 1962, has accepted a permanent appointment at the London headquarters of the Authority, where he will retain his post as technical director in addition to becoming deputy to the chief executive, Mr. C. I. Meek. Mr. Eddie was the first head of the Industrial Development Unit of the Authority, which was established in Hull just over two years ago, and his place as head of the unit will be taken by Mr. R. Bennett.

THE second international congress on "Hormonal Steroids" will be held in Milan during May 23-28. Further information can be obtained from Dr. L. Martini, Department of Pharmacology, 21 Via Andrea del Sarto, Milan.

THE annual delegate conference of the Institution of Professional Civil Servants will be held at Eastbourne during May 24-26. Further information can be obtained from the General Secretary, Institution of Professional Civil Servants, Northumberland Street, London, W.C.2.

A ONE-DAY course on "Fine Structure in Biological Tissues", arranged by the Joint Biology Committee, will be held in the University of London on May 22. The programme will include: fine structure and function in plant cells; the shapes of molecules; exploring the brain with the electron microscope; a molecular basis for the transmission of genetic information. Furthor information can be obtained from the Treasurer, Joint Biology Committee, $11 a$ Lonsdale Gardens, Tunbridge Wells, Kent.

ERratum. It is regretted that the illustration in the communication entitled "Linearization of Evoked Responses to Sine Wave-modulated Light by Noise", which appeared on p. 913 of the February 27, 1965, issue of Nature, was inadvertently cut on the left-hand side. The complete figure is reproduced here.

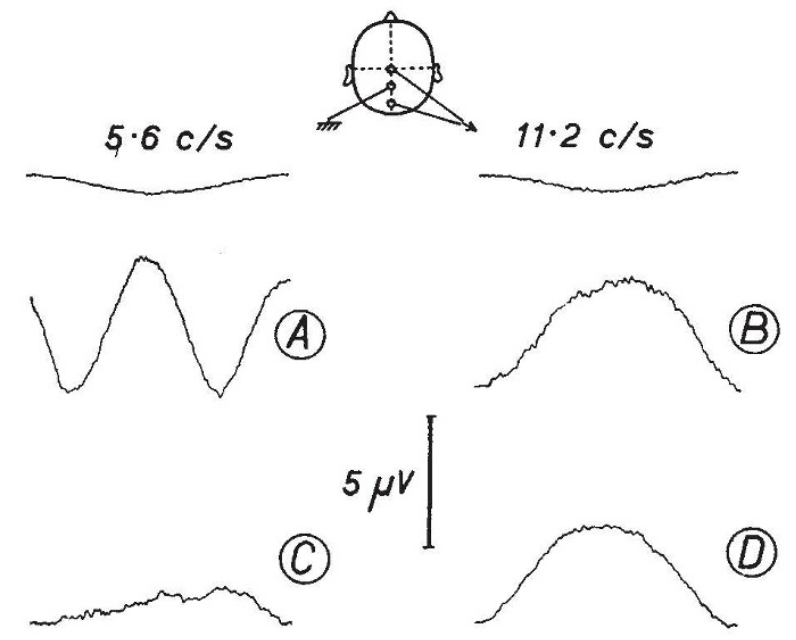

